\title{
Preliminary Survey of Lizards of Pantai Melawi, Bachok, Kelantan, Malaysia
}

\author{
Siti Zaleha Mat Diah, Rosli Hashim, Yong Hoi Sen, Daicus Belabut, Syuhadah Dzarawi N., \\ and Lim Boo Liat ${ }^{1}$
}

Institute of Biological Sciences, Faculty of Science, University of Malaya, 50603 Kuala Lumpur, Malaysia.

${ }^{1} 12$ Jalan Koop Cuepacs, Taman Cuepacs, 43200 Cheras, Selangor, Malaysia

Received on $18^{\text {th }}$ July 2009, accepted in revised form $27^{\text {th }}$ November 2009.

\begin{abstract}
A survey of lizards was conducted of Pantai Melawi, Bachok on 12-14 April and 11-13 May 2009. Nine species of lizards were recorded in this preliminary survey. They were from the family Agamidae (Calotes versicolor, Leiolepis belliana), family Gekkonidae (Cosymbotus platyurus, Gehyra mutilata, Gekko monarchus, Gekko gecko and Hemidactylus frenatus), family Scincidae (Eutropis multifasciata) and family Varanidae (Varanus salvator). The common species in this area were Leiolepis belliana and Hemidactylus frenatus.
\end{abstract}

\begin{abstract}
ABSTRAK Pemerhatian cicak dijalankan di Pantai Melawi, Bachok pada 12-14 April dan 11-13 Mei 2009. Sembilan spesies cicak telah direkodkan dalam bancian awal ini. Cicak yang dikenalpasti adalah dari famili Agamidae (Calotes versicolor, Leiolepis belliana), famili Gekkonidae (Cosymbotus platyurus, Gehyra mutilata, Gekko monarchus, Gekko gecko dan Hemidactylus frenatus), famili Scincidae (Eutropis multifasciata) dan famili Varanidae (Varanus salvator). Spesies yang umum di kawasan ini ialah Leiolepis belliana dan Hemidactylus frenatus.
\end{abstract}

(Keywords: reptile, lizard, coastal fauna, Pantai Melawi)

\section{INTRODUCTION}

Melawi ( $\left.6^{\circ} 1^{\prime} 0 \mathrm{~N} ; 102^{\circ} 25^{\prime} \mathrm{OE}\right)$ is located in Bachok, 25 kilometers east from Kota Bharu, Kelantan Darul Naim, Peninsular Malaysia. It borders Pasir Puteh to the south and Kota Bharu to the west. It cover an area of about 4 ha and is situated along the South China Sea. The proposed research station of the University of Malaya is situated here. The area is an old coconut plantation surrounded by a small village of about 50 households. It is 100 meters long from the beach to the north and demarcated by a river (about 1 meter wide) to the south.

All the coconut palms (Cocos nucifera) at the proposed research station of the University of Malaya are very old and too tall for human harvesting. The ground was covered with a lot of coconut palm leaves and stems, and coconut shells are scattered here and there. The vegetation in the study area includes grasses, bushes, Casuarina equisetifolia and Pandanus tectorius. The field is abounded with nest holes principally by the Butterfly lizard (Leiolepis belliana) and possibly other ground dwelling lizards and snakes.

Herpetofaunal records on sandy habitats of Peninsular Malaysia, especially at the coastal area are mainly on sea turtles [1, 2, 3, 4, 5, 6], sea snakes [7] and butterfly lizard [8]. There appears to be little information on other lizards as well as other terrestrial reptiles.

Lizards occur from deserts to the Arctic tundra, and exposed mountain slopes to isolated islands [9]. In 1991, 96 species of lizard were reported in Peninsular Malaysia [10]. Since then more species that are new have been discovered.

In the course of biodiversity survey at the University of Malaya, Bachok surveys of reptiles were carried out. This paper reports the lizards recorded at Pantai Melawi, Bachok, Kelantan Darul Naim during two surveys conducted in 2009.

\section{MATERIALS AND METHODS}

The first survey was carried out for three days and two nights. On the first day, observations started in the afternoon (about $5.00-7.00 \mathrm{pm}$ ) and continued at night (about $9.00-12.00 \mathrm{pm}$ ); on the second day also in the afternoon (about $2.00-5.00 \mathrm{pm}$ ) and continued at night (about $8.00-10.00 \mathrm{pm}$ ). On the last day, observation was conducted only in the morning (about $8.30-9.30 \mathrm{am}$ ). The animals were observed directly, photographed and caught by hand. For the Butterfly lizards they were caught by using a method akin to fishing technique. The specimens collected were measured and preserved in $10 \%$ formalin before storing in $75 \%$ alcohol. Some specimens were only photographed. 


\section{RESULTS AND DISCUSSION}

Some 90 lizards comprising nine species were observed and/or caught in this survey (Table 1). Leiolepis belliana (29 individuals) and Hemidactylus frenatus (46 individuals) were the commonest species. Indeed many more individuals were encountered but not recorded. The nest holes of $L$. belliana could be easily seen scattered in the sandy area (Figure 1). It is a ground dwelling lizard inhabiting burrows in sandy places, and is especially abundant in the flat sandy places near coastal areas [11]. This species is well known in Malay society as 'Biawak pasir' [12].

Geckos occur widely in the study area. Of the nine species of lizards, five were the geckos. Most of geckos were found on coconut trunk. Hemidactylus frenatus was found both on the coconut trunk and on the walls of building. On the other hand Cosymbotus platyurus was only found on the wall of building.
In addition to the lizards, one species of snake (Monocellate cobra Naja kaouthia) was encountered during the surveys. No turtles and tortoises were seen. We however did not look systematically for sea and water snakes although the area might support these reptiles.

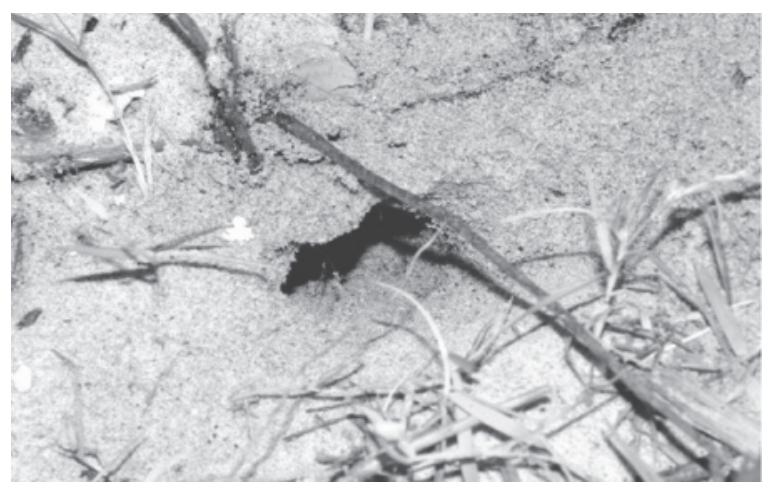

Figure 1. A nest of Butterfly lizard.

Table 1. Lizards recorded at Pantai Melawi, Bachok, Kelantan.

\begin{tabular}{lcc}
\hline \multicolumn{1}{c}{ Species } & Family & Number of individuals \\
\hline Calotes versicolor & Agamidae & $2 \mathrm{~s}$ \\
Leiolepis belliana & Agamidae & $27 \mathrm{~s} 2^{*}$ \\
Hemidactylus frenatus & Gekkonidae & $40 \mathrm{~s} 6^{*}$ \\
Gehyra mutilata & Gekkonidae & $2 *$ \\
Cosymbotus platyurus & Gekkonidae & $2 \mathrm{~s} 1^{*}$ \\
Gekko monarchus & Gekkonidae & $2 \mathrm{~s}$ \\
Gekko gecko & Gekkonidae & $1+$ \\
Eutropis multifasciata & Scincidae & $1 *$ \\
Varanus salvator & Varanidae & $3 \mathrm{~s}$
\end{tabular}

. (s = sighted, ${ }^{*}=$ caught, $+=$ calls heard $)$

\section{SPECIES ACCOUNT}

Family Agamidae

Calotes versicolor (Daudin, 1802)

The Garden Fence Lizard (Figure 2) can be identified by its two spines above the tympanum, the absence of spine behind the eye, and the absence of a shoulder fold [8]. It is common in open areas like gardens, parks, agriculture areas and open forest. It occurs in all the states in Peninsular Malaysia [13, 14, 15] and is an introduced species in Singapore [16].

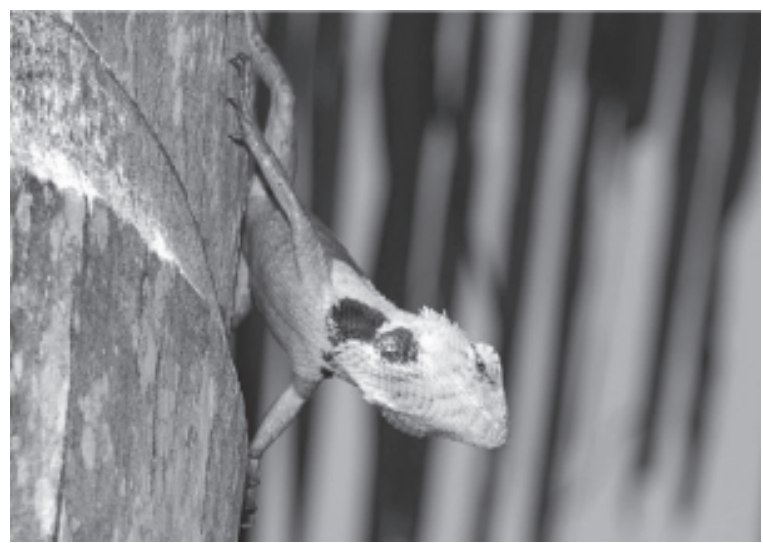

Figure 2. Calotes versicolor (Male) 
Leiolepis belliana belliana Gray, 1831

The Butterfly Lizard (Figures 3 and 4) is strictly associated with sandy habitat and is very common in the east coast of Peninsular Malaysia. It is also a common inhabitant in Pulau Langkawi, Kedah. The failure to detect this species in the coastal region of the western part of Peninsular Malaysia does not necessarily mean it is absent completely. This lizard requires further research, particularly its distribution pattern.

The genus Leiolepis Cuvier, 1827 is closely related to the Afro-Asian genus Urosmastyx Merrem, 1820. The present classification places it as a member of the Agamidae [17]. Before this, it was placed under the Uromasticidae $[8,10]$.

Only a single species occurs in Peninsular Malaysia [10]. The common name, Butterfly Lizard, is probably derived from its long free ribs that enable it to flatten its body dorsal-ventrally and display its orange-and-black barred sides that somewhat resemble butterfly wings [8].

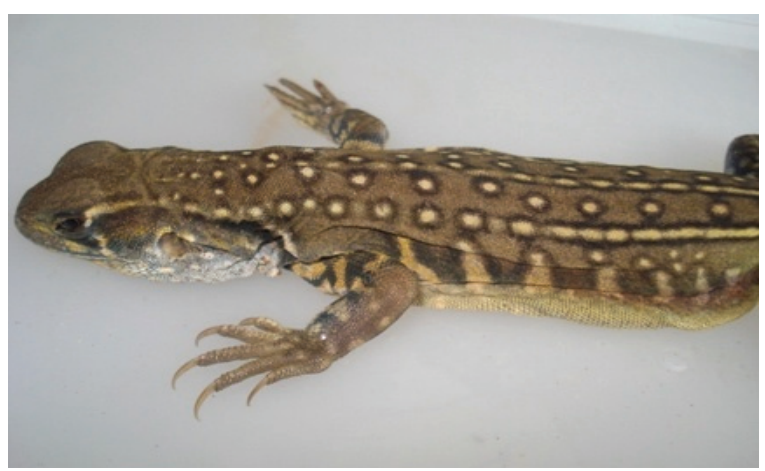

Figure 3. Leiolepis belliana (adult)

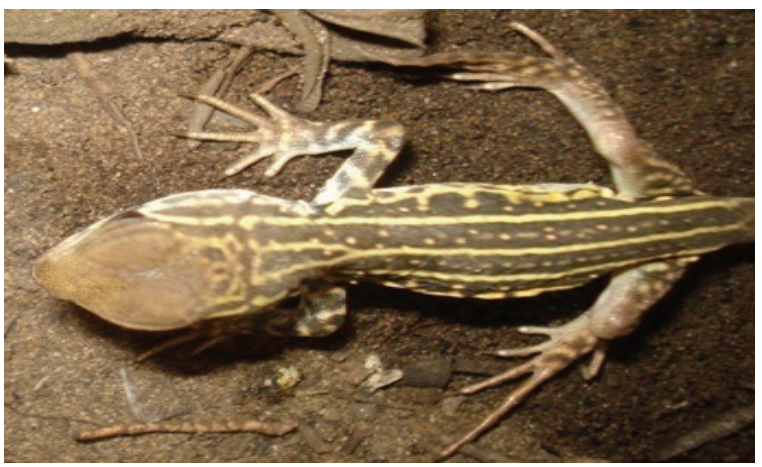

Figure 4. Leiolepis belliana (juvenile)

Family Gekkonidae

Hemidactylus frenatus Dumeril \& Bibron, 1836

The Spiny-tailed House Gecko (Figure 5) is a common species in human habitat. They can be seen climbing walls of houses and other buildings in search of insects attracted to porch lights,

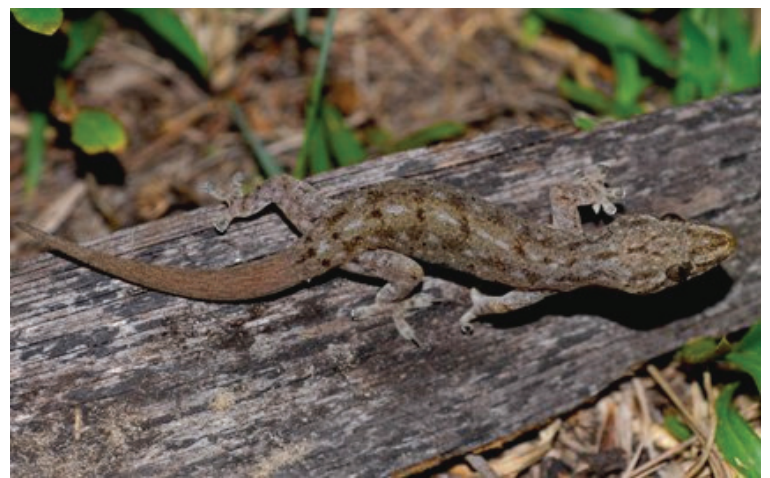

Figure 5. Hemidactylus frenatus

hence their common name. Notably in Malaysia and Singapore geckos have local names onomatopoetically derived from the sounds they produce - "chee chak" or "chi chak" [18].

\section{Gehyra mutilata (Weigmann, 1835)}

The Four-clawed Gecko (Figure 6) is more an outdoor species, usually found in coconut plantation. It invades houses where there are coconut palms around, but it is a common house gecko in Penang and Singapore. The specimen in the present report was caught on a coconut trunk.

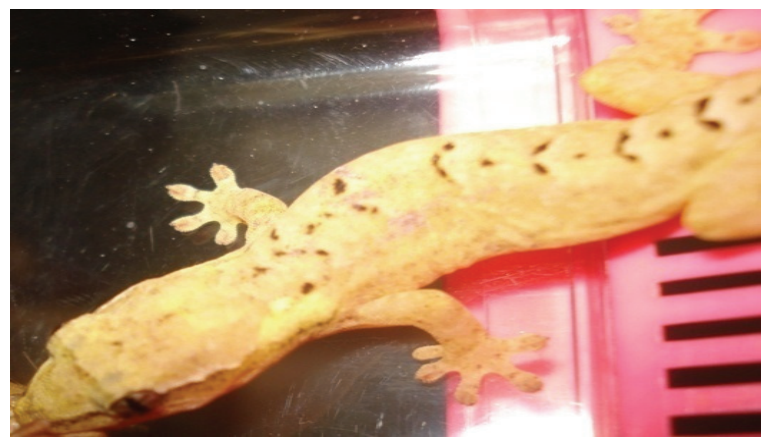

Figure 6. Gehya mutilata (female)

The Four-clawed Gecko's common name is derived from the absence of a claw on the inner digit of its fore and hind feet. The other toes and fingers are equipped with well-developed, curved claws [8].

Gekko monarchus (Dumeril \& Bibron, 1836)

The Spotted House Gekko is pale grey or fawn in colour with pairs of dark blotches over the spine. It is common throughout Peninsular Malaysia particularly in Penang, Perak, Selangor and Kelantan [13]. It is active at night. This gecko inhabits both building and the forest up to $1500 \mathrm{~m}$ above sea level.

Cosymbotus platyurus (Schneider, 1792)

The Flat-tailed Gecko is recognized by its flattened tail, the webbing at the base of the fingers and toes and the fringe of skin along the body. It is common in human habitat of Malaysia. 
Gekko gecko gecko (Linnaeus, 1768)

The Tokay is a noisy lizard, more often heard than seen. It has orange or red spots on the body. Tokays are renowned for their loud vocalizations 'túc-key', repeated several times; only male makes a loud call [3]. This is a nocturnal arboreal gecko.

\section{Family Scincidae}

Eutropis multifasciata (Kuhl, 1820)

The Many-lined Sun Skink was previously referred to as Mabuya multifasciata (Kuhl, 1820). It is active during the day in sunshine, basking or foraging. This skink has a tail less than twice as long as the body.

\section{Family Varanidae}

Varanus salvator salvator (Laurenti, 1786)

The Water Monitor is one of the largest lizards in the world [8]. Two individuals were sighted in the river. This species is commensal in distribution and not habitat specific, but is more common in mangrove forest. It occurs throughout Peninsular Malaysia [10].

\section{ACKNOWLEDGEMENTS}

We would like to extend our gratitude to various parties for making this study possible. Financial support for this study was provided by grant PJPFS295/2008A awarded to Prof. Rosli Hashim.

\section{REFERENCES}

1. Balasingam, E. (1965). Turtle Conservation Results of 1965 Hatchery Programme. Malayan Nature Journal 20: 139 - 141

2. Balasingam, E. (1965a). The Giant Leathery Turtle Conservation Programme, 1964. Malayan Nature Journal 19: 145 - 146

3. Balasingam, E. (1965b). Conservation of Green Turtle (Chelonia mydas) in Malaya. Malayan Nature Journal 19: 235 - 236

4. Kiew, B.H. (1984). Conservation Status of the Malaysian fauna. IV. Turtles, Terrains and Tortoises. Malaysian Naturalist 38 (2): 2- 3

5. Chan, E.H. and Liew, H.C. (1989). The Leatherback Turtle. A Malaysian Heritage. Tropical Press Snd. Bhd. Kuala Lumpur. pp. 49

6. Liew, H.C., Can, E.H., Papi, F. and Litschi, P. (1996). Long distance Migration of Green Turtles from Redang Island, Malaysia: The need for Regional Cooperation in Sea Turtle Conservation. Devaux, B (ed.). pp. 73 - 75. In: Proceeding of the International Congress of Chelonian Conservation. Editions Soptom, Gonfron

7. Lim, B. L. (1991). Poisonous Snakes of Peninsular Malaysia. Malayan Nature Society, Kuala Lumpur, Malaysia. 74pp.
8. Cox, M. J., P.v.D. Peter, J. Nabhitabhata \& K. Thirakhupt. (1998). A Photograpic Guide to Snakes and Other Reptiles of Peninsular Malaysia, Singapore and Thailand. New Holland, Pubslisers (UK) Ltd. 144 pp.

9. Taylor, B. \& M. O'Shea. (2006). The Great Big Book of Snakes \& Reptiles. Hermes House, London. Pp255

10. Denzer, W. \& U. Manthey. (1991). A Nominal Checklist of the Lizards inhabiting Peninsular Malaysia and Singapore. Raffles Bulletin of Zoology, 39 (2): 309-322.

11. Krishnasamy, M., S. Ambu, S. K. Inder, H. L. Lee \& J. Jeffrey. (2003). A Preliminary study of the lizard (Agamidae) Leiolepis bellina belliana Gray, 1827 from the east coast of Peninsular Malaysia. Tropical Biomedicine 20 (1): 99-101

12. Siti Zaleha Mat Diah, Rosli Hashim \& Yong Hoi Sen. (2008). Biawak Pasir. Dewan Kosmik, Jilid 16 bil 02. Dewan Bahasa dan Pustaka: 27-28

13. Boulenger, G. A. (1912). A vertebrate fauna of the Malay Peninsula from the Isthmus of Kra to Singapore including the adjacent islands. Reptilia and Batrachia. Taylor \& Francis, London: I-XIII, 1-294.

14. Sworder, G. H. (1925). The Lizards of Singapore Island. Singapore Nat., 5: 61-68

15. Taylor, E. H. (1963). The Lizards of Thailands. Univ. Kansas Sci. Bull., 44 (14): 687-1077

16. Lim, K. K. P \& L. M. Chou. (1990). The herpetofauna of Singapore. In: essays in Zoology.

17. Krysko, K. L. \& K. M. Enge (2005). A New Non-native lizard in Florida, The Butterfly Lizard, Leiolepis belliana (Sauria: Agamidae). Florida Scientist, 68 (4): 247-249.

18. Marcellini, D. (1977). Acoustic and Visual Display Behavior of Gekkonid Lizards. American Zoologist, 17 (1): 251-260 